\title{
Post-Damage Repair of Prestressed Concrete Girders
}

\author{
Chris Ramseyer ${ }^{1)}$, and Thomas H.-K. Kang ${ }^{2), *}$
}

(Received July 22, 2012, Accepted August 3, 2012, Published online September 18, 2012)

\begin{abstract}
Concrete is an economical construction material and for that reason it is widely used in buildings and infrastructures. The use of deicing salts, expansion joint failure, and freeze-thaw cycles have led to concrete bridge girders experiencing corrosion of steel reinforcement and becoming unsafe for driving. The goal of this research is to assess the effectiveness of current and possible repair techniques for the end region of damaged prestressed concrete girders. To do this, three American Association of State Highway and Transportation prestressed concrete girders were tested to failure, repaired, and retested. Three different repair materials were tested including carbon fiber, glass fiber, and surface mounted rods. Each different repair material was also tested with and without injected epoxy. Comparisons were then made to determine if injecting epoxy had a positive effect on stiffness and strength recovery as well as which repair type regained the largest percentage of original strength.
\end{abstract}

Keywords: prestressed concrete, post-damage repair, shear strengthening, FRP, surface mounted rods.

\section{Introduction}

The national transit system plays a large role in economy and society. More than $60 \%$ of the total bridge inventory in the United States are made of concrete and is reinforced concrete (U.S. Department of Transportation 2004). Over the past 40 years the rate of deterioration of concrete has increased due to increased use of deicing salts. Although deterioration of concrete structures over time is normal and expected, the rate at which this has occurred for highway bridges since the 1960s, when officials began applying deicing salts in the winter, has been abnormally advanced and has posed significant challenges, both economically and technically. The deterioration is a consequence of the aggressive nature of chloride ions. This has led to a direct annual cost of 5.7-9.7 billion dollars (Koch et al. 2002). If indirect costs are included the cost increases roughly ten times (Yunovich et al. 2003). An investigation conducted by the Michigan Department of Transportation indicated that for prestressed concrete I-beams, repair ranges from 35 to $69 \%$ the cost of the superstructure replacement (Needham 2000).

Concrete is generally considered a durable material but is subject to deterioration caused by mix design, environmental effects, and corrosion of the embedded reinforcement.

\footnotetext{
${ }^{1)}$ School of Civil Engineering and Environmental Science, University of Oklahoma, Norman, OK 73019, USA.

${ }^{2)}$ Department of Architecture and Architectural Engineering, Seoul National University, Seoul 151-744, Korea.

*Corresponding Author; E-mail: tkang@snu.ac.kr Copyright ( $\odot$ The Author(s) 2012. This article is published with open access at Springerlink.com
}

Improper aggregate type and sizing, calcium chloride, and alkali-aggregate interactions are a few of the material problems. Environmental effects include expansion and contraction due to absorption of moisture followed by a freeze-thaw cycle. This causes the concrete to crack and may lead to significant damage or failure. End region concrete deterioration of prestressed concrete girders tends to be exacerbated when the expansion joint located at the deck level above the beam end fails and all of the deicing salts drain over the beam ends (Yeager 2007). A partially fixed girder end, such as one created by a frozen bearing, may impose additional stress at the girder end. When the stress build-up is relieved, tension cracks or shear cracks may result (Emmons 1994).

Moisture absorbed by concrete expands and contracts with temperature changes and the resulting mechanical action can cause cracks, fractures, and spalling. Airborne compounds, such as carbon dioxide, can also cause adverse chemical reactions which can lead to surface deterioration (Freeman et al. 1999). When a concrete structure is often exposed to deicing salts, salt splashes, salt spray, or seawater, chloride ions from these will slowly penetrate into the concrete. The chloride ions eventually reach the steel and then accumulate beyond a certain concentration level. The protective passivity is destroyed and the steel begins to corrode, since oxygen and moisture are present at the steel-concrete interface. Cracking and spalling may occur in the concrete due to the formation of voluminous corrosion products, which are up to six times the volume of the original steel. Corrosion of the reinforcing steel and prestressing strands at the end of the girder is the most destructive deterioration mechanism for reinforced concrete bridges in the United States (Weyers et al. 1993).

The objective of the research is to investigate the feasibility of methods to repair end damage or strengthen against end damage in American Association of State Highway and 


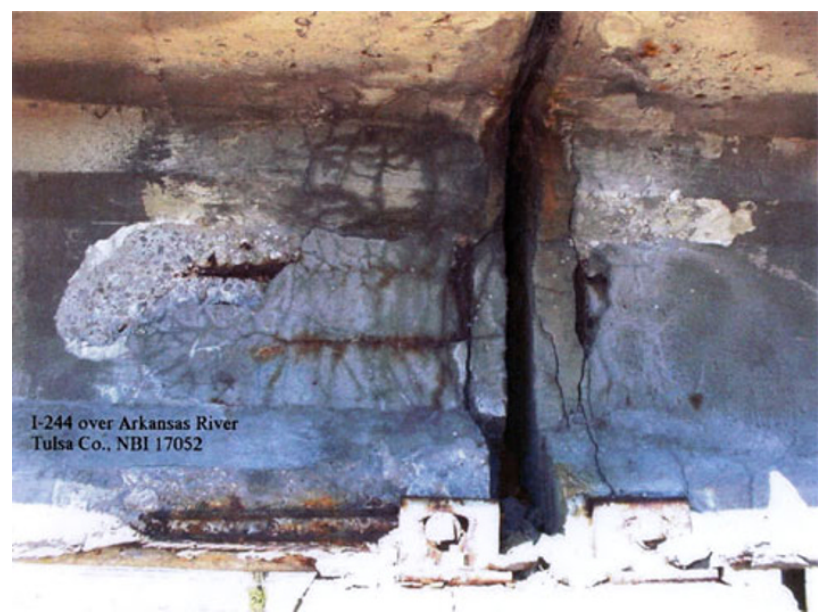

Fig. 1 Damage in the end region of an AASHTO bridge girder.

Transportation (AASHTO) prestressed concrete bridge girders. Note that to the authors' knowledge, no research has been conducted, nor are there any prediction models available on the shear strength of post-repaired beams that experienced shear failure prior to the repair. Figure 1 shows damage in the end region of an AASHTO bridge girder on I-244 over the Arkansas River in Tulsa County, Oklahoma, U.S.A.

Several methods of repair for AASHTO girders are being used at the present time. These include wraps, U-jackets, and near surface mounted rods. Wraps are impractical because they require access to the top of the beam which is most likely covered by the deck and are also expensive. U-jackets are also expensive but do not require access to the top of the beam. Near surface mounted rods are a less expensive alternative if they can recover strength to the beam, but they also require access to the top of the beam.

These methods are known to work; however, full-scale structural performance testing on the repair of the prestressed concrete bridge end region (both undamaged and damaged) is still lacking and there is also not much direct comparison between the methods. The research program examined the effectiveness of three post-damage repair methods including near surface mounted rods, and two types of fiber reinforced polymers. Also, the research investigates whether or not the injection of a high strength-high strain cement-epoxy into the cracked section will help increase the bearing capacity. Additionally, the research is devised to test the effects of adding a distribution plate along with the surface mounted rods. The ultimate goal of this experiment is to find the best, cost effective, most convenient way to repair damaged AASHTO prestressed concrete girders.

\section{Tests of Undamaged Prestressed Concrete Girders}

\subsection{Bending Tests}

For the bending test setup, full-scale Type II AASHTO girders with a depth of $915 \mathrm{~mm}$ (36 in.) and an area of $2,380 \mathrm{~cm}^{2}\left(369 \mathrm{in}^{2}\right)$ were placed on simple supports located

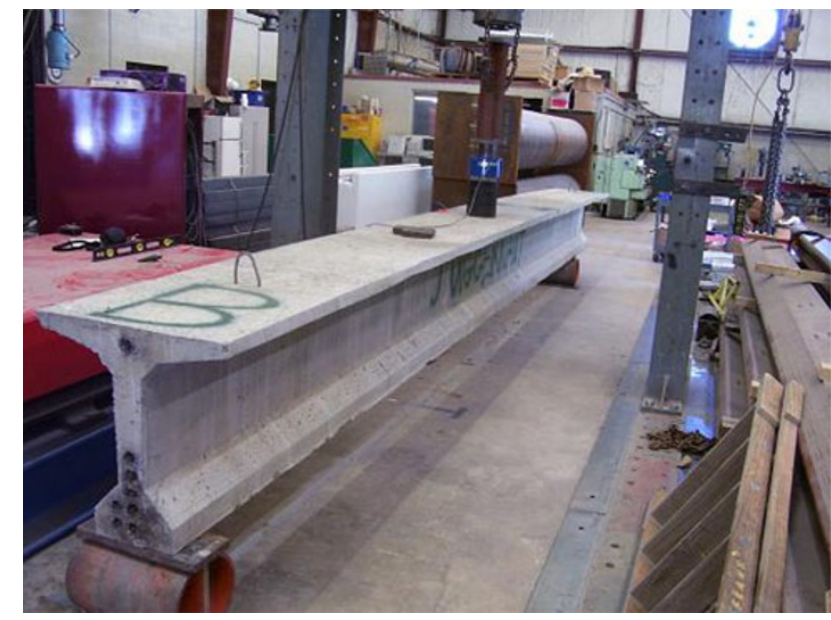

Fig. 2 Beam during bending test.

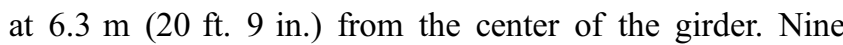
$15.2 \mathrm{~mm}$ (0.6 in.) diameter Grade 270 seven-wire strands were used as tensile longitudinal reinforcement, and the specified concrete strength was $40 \mathrm{MPa}(6,000 \mathrm{psi})$. The beams were supported on the rollers with one end above the roller and the other end extending $914 \mathrm{~mm}$ (three feet) past the support to keep the ends independent of each other (Figs. 2, 3). This independence was necessary due to the destructive shear testing of the beam ends later in the test series. Note that all the tested beams had the same conditions and materials.

The load was applied using a $1,780 \mathrm{kN}$ (400 kip) hydraulic cylinder mounted to a testing frame. A grout pad was placed directly on the beam surface and a steel plate was placed on top of the leveler. A $445 \mathrm{kN}$ (100 kip) load cell was put in place with a steel cylinder on top of the load cell to provide good contact and protect the cell. Finally, a metal box-frame extension was included to close the gap between the hydraulic cylinder and the rest of the testing equipment. This extension was loosely supported by chains as a safety precaution in case the loading apparatus happened to fall (Fig. 4). The vertical deflection measurements were taken using a string potentiometer which was attached to the top flange of the beam by a clamp and small diameter bent metal rod. Deflection and load measurements were collected and recorded by the data acquisition system.

The hydraulic cylinder was used to load the beams until a deflection of $7.5 \mathrm{~mm}$ (0.3 in.) was measured, at which point a moderate degree of flexural damage in the elastic stress range was expected to occur. Both load and deflection were recorded simultaneously over the course of the test. After reaching $7.5 \mathrm{~mm}(0.3 \mathrm{in}$.) of deflection, the beams were unloaded at a controlled pace to keep the beams from rebounding past their normal state and possibly causing damage. The beam would then be moved $914 \mathrm{~mm}(3 \mathrm{ft})$ and the test repeated for the other end.

\subsection{Shear Tests}

After the bending tests had been completed for both ends the ultimate shear capacity was tested. The beam end was failed in shear to determine their strength and also to simulate a corrosively failed end region. For this test each beam 

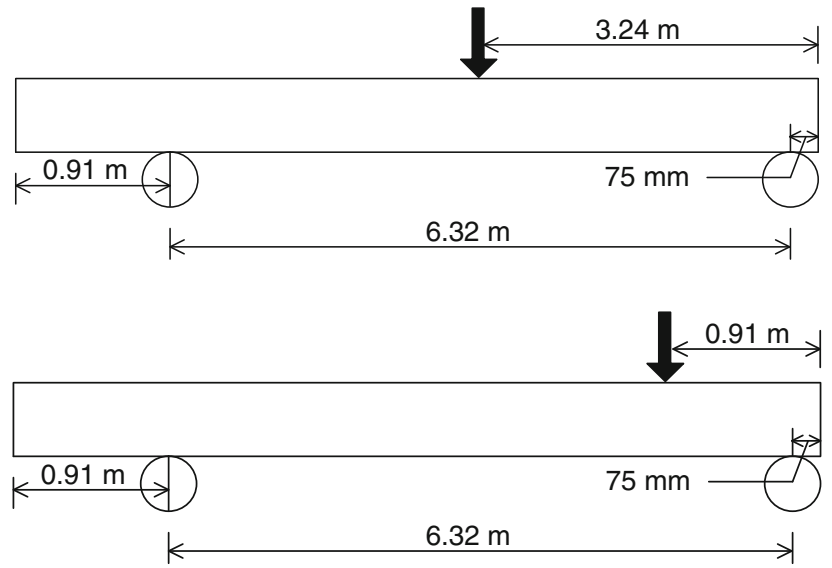

Fig. 3 Location for loading points and supports during bending and shear tests.

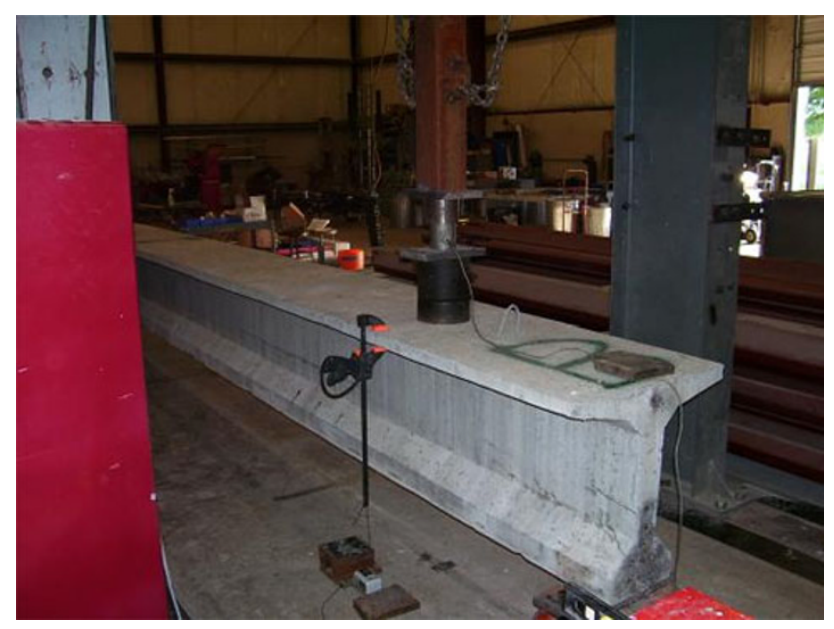

Fig. 4 Beam during shear test.

was supported with the same distance from each end, as was done in the bending test; however, the load was applied only $914 \mathrm{~mm}$ (3 ft) from the end in question (Figs. 3, 4).

The loading stack used in the shear test was similar to that of the bending test, except a load cell with a larger capacity $(1,335 \mathrm{kN} ; 300 \mathrm{kip})$ was used. Vertical deflection measurements were also taken during this test and the set up was the same as it was for the bending tests.

During the shear test, the beam was incrementally loaded and cracks were identified between loading increments. The beam was then loaded until the beam reached a maximum load after which the beam yielded so much that the beam could not hold any more load. The process was then repeated for the other end.

\section{Post-Damage Repair and Post-Repair Testing}

\subsection{Post-Damage Repair}

The fiber and epoxy repairs to the beams were done by a professional concrete service firm in Oklahoma, and the surface mounted rod repairs were installed by the research assistants of the University of Oklahoma. Repairs were begun by removing the loose concrete from the ends of the beams. Rapid set cement was added to ends where there was a significant amount of missing concrete (Fig. 5).

One end of each beam was epoxy-injected. To accomplish this, toothpicks were placed in the cracks then small tubes were placed over the toothpicks. Putty was added to seal off the cracks and hold the tubes in place. When the putty was cured the toothpicks were removed and epoxy was then injected under pressure through the tubes and into the cracks. The tubes were then capped off. Once the epoxy had cured the putty and tubes were ground off so the surface was smooth. Two types of FRP sheets were applied: carbon FRP and glass FRP. The fiber was soaked in a saturate then placed over the primer and putty. Rollers were used to remove surface imperfections. Grooves were cut in the beams and metal rods were placed in them to hold the fiber sheets in place. A diagram showing FRP dimensions is presented in Fig. 6.

While the FRP repairs were curing the surface mounted rod repair was conducted for the last beam. It was decided to use five sets of stirrups on each end, evenly spaced out over the crack area, to complete the repairs. Threaded steel rods with a diameter of $19 \mathrm{~mm} \mathrm{(3/4} \mathrm{in.)} \mathrm{were} \mathrm{used} \mathrm{in} \mathrm{conjunction} \mathrm{with}$ $76 \times 76 \times 6.35 \mathrm{~mm}(3 \times 3 \times 1 / 4$ in. $)$ angle steel to create the stirrups. The angle steel was cut into $406 \mathrm{~mm}$ (16 in.) lengths and had two $0.8125 \mathrm{~mm}$ (13/16 in.) holes drilled into one side so that the closest edges of the holes were $254 \mathrm{~mm}$ (10 in.) apart. This hole placement allowed the steel rods to pass just on either side of the bulb on the beam (Fig. 7).

A template was made to allow for quick hole placement. Then using the hammer drill, a hole was drilled through the top flange of the concrete so that the rods could be connected to a piece of angle steel on top of the flange. The rods were then hand-tightened until flush against both the bottom of the bulb and the top of the flange. With the repairs complete, the repaired sections was retested.

\subsection{Post-Repair Tests}

Once the repairs were finished, the bending and shear tests were repeated as previously described. The load was not paused during the loading process to mark the cracks because they could not be seen due to the repairs (Fig. 5). Also, on the final tests a piece of neoprene was placed on top of the plate that was on the roller to even out the uneven surface of the bottom of the beam.

\subsection{Additional Testing with Distribution Plate}

During the testing of the repaired ends, a trend was noticed. In every beam, bulb deterioration was the first sign of (bearing) failure or, in a couple of cases, the only noticeable failure point. To resolve this, a distribution plate was added to the beam with the surface mounted rod repair to decrease the concentration of stress in the $152 \mathrm{~mm}$ (6 in.) of the bulb resting on the support. A $25.4 \mathrm{~mm}$ (1 in.) thick steel plate with the same width as the lower bulb that extended $533 \mathrm{~mm}$ (21 in.) from the end of the beam was secured between the steel rods and the bottom of the beam. The beam was then re-retested as described in the preceding sections. 


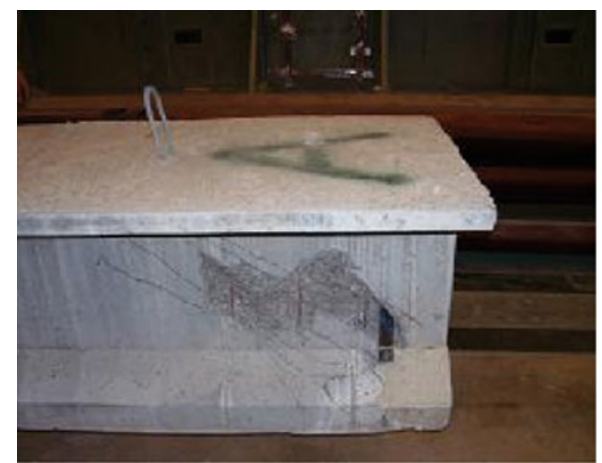

(a) Missing concrete

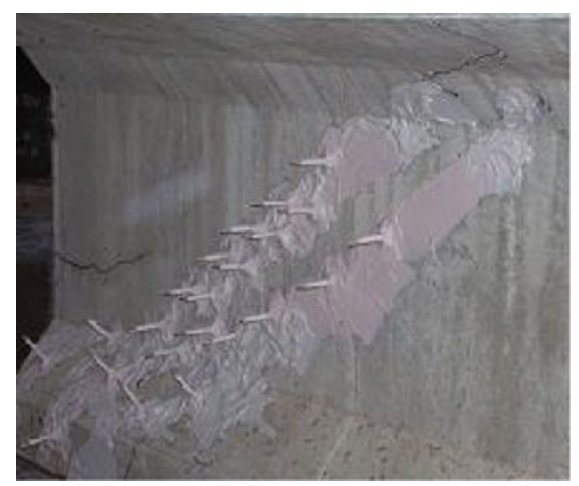

(c) Epoxy injection tubes

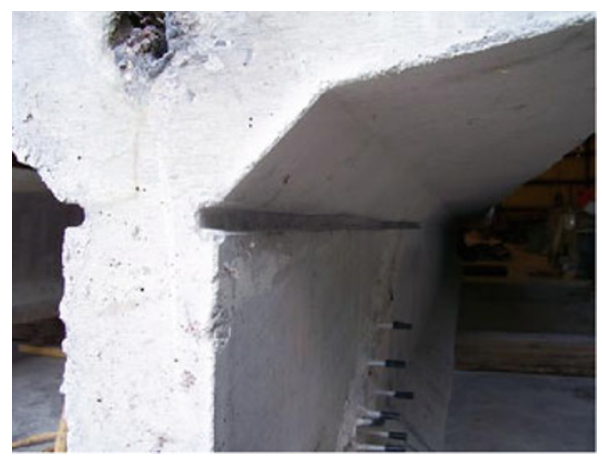

(e) Trench cut in top of beam web

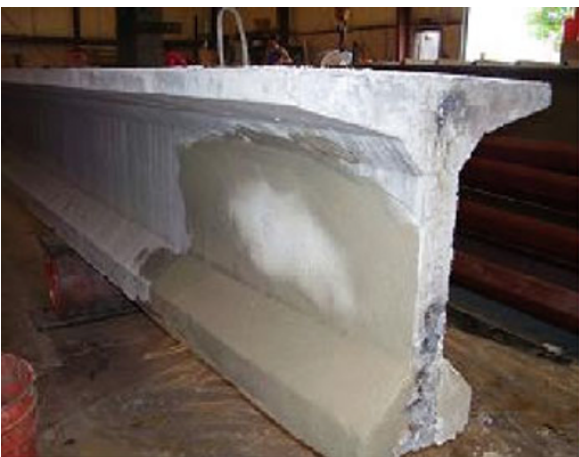

(b) Rapid set cement repair

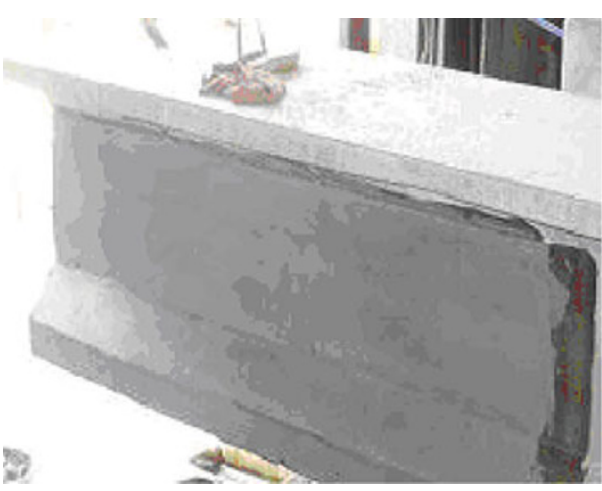

(d) Primer and putty

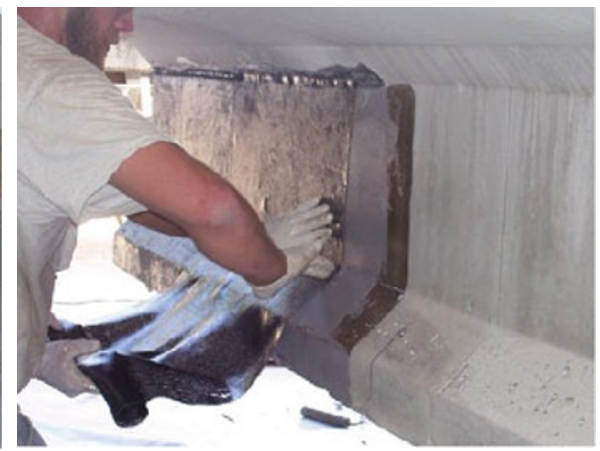

(f) Carbon FRP being applied

Fig. 5 Beam post-damage repair.
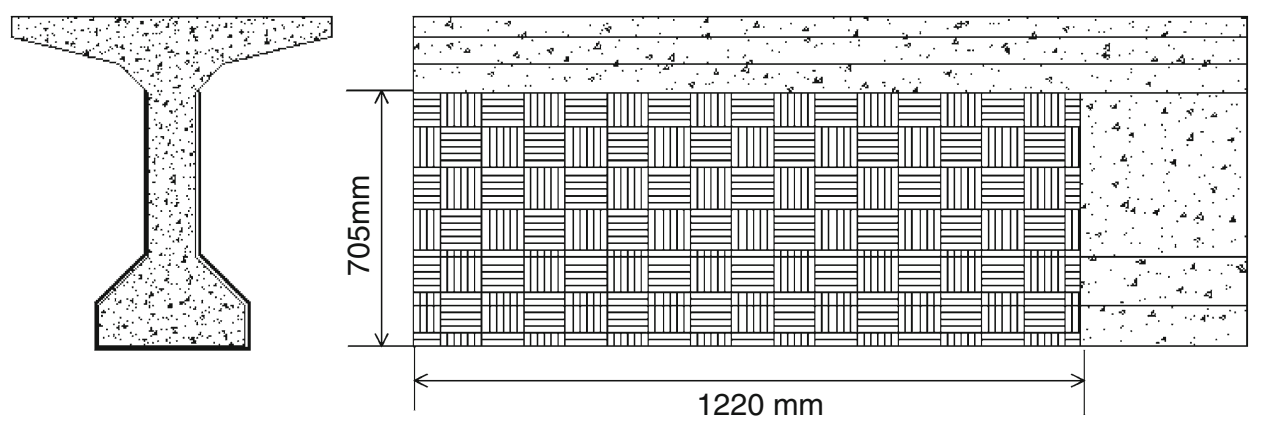

Fig. 6 Configuration of FRP application to the AASHTO prestressed concrete girder.

\section{Results and Discussion of Experimental Research}

The results of the initial tests and tests after post-damage repair are presented in Table 1 . The percent of strength regained by each repair method is presented in Table 2 . Note that all the tested prestressed concrete AASHTO girders had the same dimensions and materials and were tested under the same conditions except for the repair method; thus, the test results provide a direct comparison between the different post-damage repair methods. As soon as the first bending post-repair test was conducted on one end (end $A$ ) of the first 


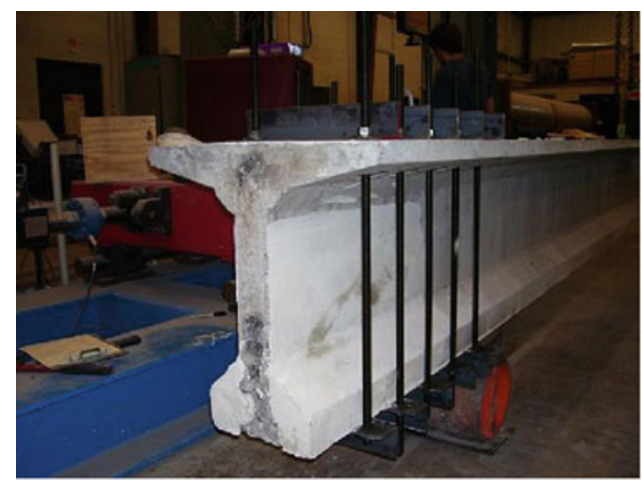

(a) Beam after steel repairs

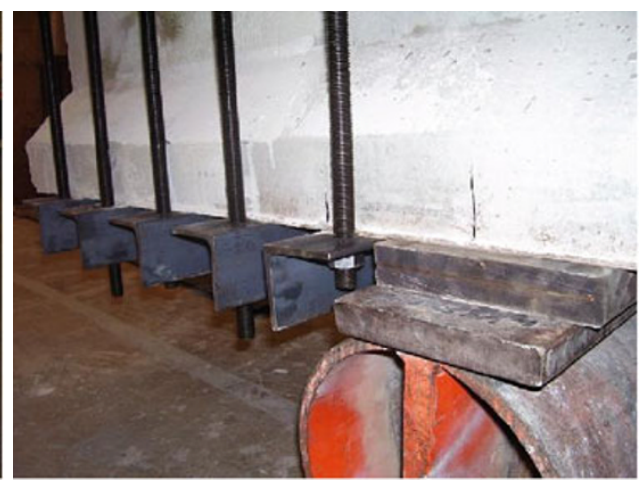

(b) Steel repair sand support

Fig. 7 Post-damage repair using surface mounted rods.

Table 1 Repair type and loadings before and after repair.

\begin{tabular}{c|c|c|c|c|c|c}
\hline Specimen ID & $\begin{array}{c}\text { Peak load during } \\
\text { initial bending test } \\
(\mathrm{kN} ; \mathrm{kips})\end{array}$ & $\begin{array}{c}\text { Peak load during } \\
\text { initial shear test } \\
(\mathrm{kN} ; \mathrm{kips})\end{array}$ & Type of repair & Epoxy injection & $\begin{array}{c}\text { Peak load during } \\
\text { post-repair bending } \\
\text { test (kN; kips) }\end{array}$ & $\begin{array}{c}\text { Peak load during } \\
\text { post-repair shear } \\
\text { test }(\mathrm{kN} \text { kips })\end{array}$ \\
\hline \hline 1A & $312 ; 70.1$ & $441 ; 99.1$ & Carbon-FRP & No & $300 ; 67.3$ & $362 ; 81.4$ \\
\hline 1B & $326 ; 73.2$ & $550 ; 123.5$ & Carbon-FRP & Yes & $300 ; 67.3$ & $391 ; 87.9$ \\
\hline 2A & $251 ; 56.5$ & $436 ; 97.9$ & Glass-FRP & No & $162 ; 36.5$ & $374 ; 84.1$ \\
\hline 2B & $288 ; 64.8$ & $473 ; 106.3$ & Glass-FRP & Yes & $222 ; 49.9$ & $481 ; 108$ \\
\hline 3A & $283 ; 63.6$ & $605 ; 135.9$ & $\begin{array}{c}\text { Surface mounted } \\
\text { rods }\end{array}$ & No & $170 ; 38.2$ & $247 ; 55.4$ \\
\hline 3B & $312 ; 70.2$ & $484 ; 108.8$ & $\begin{array}{c}\text { Surface mounted } \\
\text { rods }\end{array}$ & Yes & $218 ; 49.1$ & $328 ; 73.8$ \\
\hline
\end{tabular}

beam (beam 1) strengthened with carbon FRP but without epoxy, the end of the beam began to fail (Fig. 8). This might have been due to the bottom surface of the beam being uneven, causing stress concentrations. As a result, a neoprene pad was added between the beam and its support to provide a better contact surface and reduce stress concentrations on the bottom bulb of the beam. However, at the end of the testing program cracking had still occurred at all of the ends not repaired with epoxy. These results indicate that the existing unrepaired cracks due to the absence of epoxy injection ended up being the cause of the problem.

Due to the damage that beam 1 end $A$ endured, its reaction point was moved $152 \mathrm{~mm}$ (6 in.) further away from the end for the rest of its testing so that it was possible to get a full test from that end of the beam. Since this moved the new load partially out of the previously failed zone, it led to the maximum load much higher than that noted in the previously failed zone.

Cracks on beam 2 end $A$ began to form during bending testing but nowhere near the extent of beam 1 end $A$, so it was left the same for later testing. The beam (beam 3) end strengthened with surface mounted rods but without epoxy (end $A$ ) cracked a considerable amount during its bending test and so it was stopped slightly early at a deflection of $6.9 \mathrm{~mm}$ (0.27 in.). Due to its repair setup a move would have been impossible with the angle steel in the way so all other testing also took place from the initial reaction point.
Several of the graphs show an initial deflection opposite of the expected (Fig. 9). This was likely a result of a combination of the beam not being exactly flush with its reaction point and the load not being applied in the direct center of the beam causing the beam to roll to one side slightly before coming to a rest, giving the initial deflection.

Tables 1 and 2 provide the data on the maximum loads that each beam end achieved for each test as well as how each was repaired and the percentage of initial loading returned after post-damage repair. The graphs shown in Figs. 9, 10 and 11 give an overview of how each beam reacted in deflection as load was applied until its maximum was reached and unloaded. The graphs also provide a comparison between how the beam reacted on its initial test and how it reacted during the tests after repairs (Fig. 10).

From the tables and graphs many comparisons can be made about the effect that epoxy injection had on the repairs. For beam 1 end $A$ repaired with carbon FRP, the results are not as conclusive due to the aforementioned problem in testing; however, comparisons can still be made. The postdamage repair job on end $B$ (epoxy-injected end) provided a peak bending load of $300 \mathrm{kN}$ (67.3 kips) and a peak shear load of $391 \mathrm{kN}$ (87.9 kips) during the shear test, giving a recovery percentage of 91.1 and $71.2 \%$ respectively. When this is compared to end $A$ (non-epoxy end), the peak loads of $300 \mathrm{kN}$ (67.3 kips) and $362 \mathrm{kN}$ (81.4 kips) were obtained from the bending and shear tests, respectively, providing 
Table 2 Repair type and percentage of loading regained.

\begin{tabular}{c|c|c|c|c}
\hline Specimen ID & Type of repair & Epoxy injection & $\begin{array}{c}\text { Percent of initial bending } \\
\text { regained (\%) }\end{array}$ & $\begin{array}{c}\text { Percent of initial shear } \\
\text { regained (\%) }\end{array}$ \\
\hline \hline 1A & Carbon-FRP & No & 96 & 82.1 \\
\hline 1B & Carbon-FRP & Yes & 91.9 & 71.2 \\
\hline 2A & Glass-FRP & No & 64.6 & 85.9 \\
\hline 2B & Glass-FRP & Yes & 60.1 & 101.6 \\
\hline 3A & Surface mounted rods & No & 69.9 & 40.8 \\
\hline 3B & Surface mounted rods & Yes & 67.8 \\
\hline
\end{tabular}

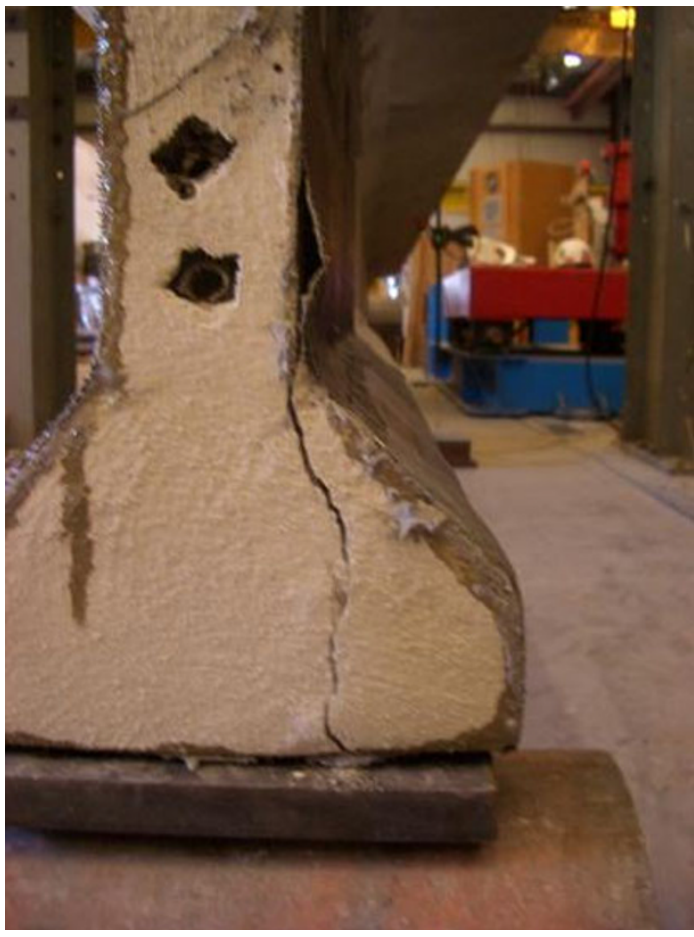

Fig. 8 Premature crack on beam 1 end $A$.

recovery of $96 \%$ in bending and $82.1 \%$ in shear. In this case, while end $B$ is better in final shear load, end $A$ ties in bending load and does better in percent recovery. However, once again this is believed to be contributed to having to move the reaction point in for end $A$ especially since this is the only end for which the end without epoxy exceeds the epoxy-injected end at all.

The data for beam 2 repaired with glass FRP follow what was initially expected, that is, end $B$ (epoxy-injected end) had a peak load of $222 \mathrm{kN}$ (49.9 kips) and $481 \mathrm{kN}$ (108 kips) during bending and shear tests, respectively, resulting in a recovery percentage of $77 \%$ in bending and $101.6 \%$ in shear. This only outperformed itself on a test after postdamage repairs. End $A$ on this beam performed reasonably well but not nearly as well as end $B$. The repairs to end $A$ provided a peak bending load of $162 \mathrm{kN}$ (36.5 kips) and a peak shear load of $374 \mathrm{kN}$ (84.1 kips) with a percent load return of $64.6 \%$ in bending and $85.9 \%$ in shear.

The beam (Beam 3) repaired with surface mounted rods also behaved as was expected with the epoxy-injected end. The epoxy-injected end (end $B$ ) was able to provide a peak load of $218 \mathrm{kN}$ (49.1 kips) during bending testing and a peak load of $328 \mathrm{kN}$ (73.8 kips) during shear testing, recovering $69.9 \%$ of its initial bending load and $67.8 \%$ of its initial shear strength. While end $A$ for beam 3 only provided a peak bending load of $170 \mathrm{kN}$ (38.2 kips) and a peak shear load of $247 \mathrm{kN}$ (55.4 kips) and was therefore able to recover $60.1 \%$ in bending and $40.8 \%$ in shear.

Figures 9, 10 and 11 show that during the bending tests both of the ends (epoxy or no epoxy) varied from their initial lines by approximately the same amount as each other of the course of the test. However, the graphs of the shear testing reveal a large difference between the injected and noninjected ends. The epoxy-injected ends were able to keep their deflection much closer to that of the original test than the ends without the injection.

Another important thing that the graphs reveal is the load (the peak of the post-repair test) a beam still supported after the loading cycle ended on its shear test. When the peaks of the repaired tests are compared to the peaks of the initial tests it can be seen that the initial shear strength was not re-gained after the FRP repair. However, the effect of adding the distribution plate was prominent. The significantly larger shear strength was obtained for the repaired beam compared with the initial shear strength (Fig. 11). It is the only one that showed potential for an increase in strength of the beam.

One of the two tests with a distribution plate showed an increase in shear strength of $43 \%$ (end $B$ ) and the other test (end $A$ ) did not show an increase; however, that end after two different failure runs was noticeably deteriorated to the point of almost being unusable. The two different failures also made the results of the end showing strength increase much more impressive. It was not stabilized, but it still outperformed all other methods.

\section{Summary and Conclusions}

From the data of undamaged and damage-repaired prestressed concrete girders described in this paper, it can be concluded that epoxy injections as an aid to repair methods provide a degree of help over beam ends not injected with epoxy. The epoxy supplies an amount of stiffness and stability to an end that has been injected. In two of the three cases the data show that the epoxy-injected beam end outperformed the regular non-injected end in every facet. In the 


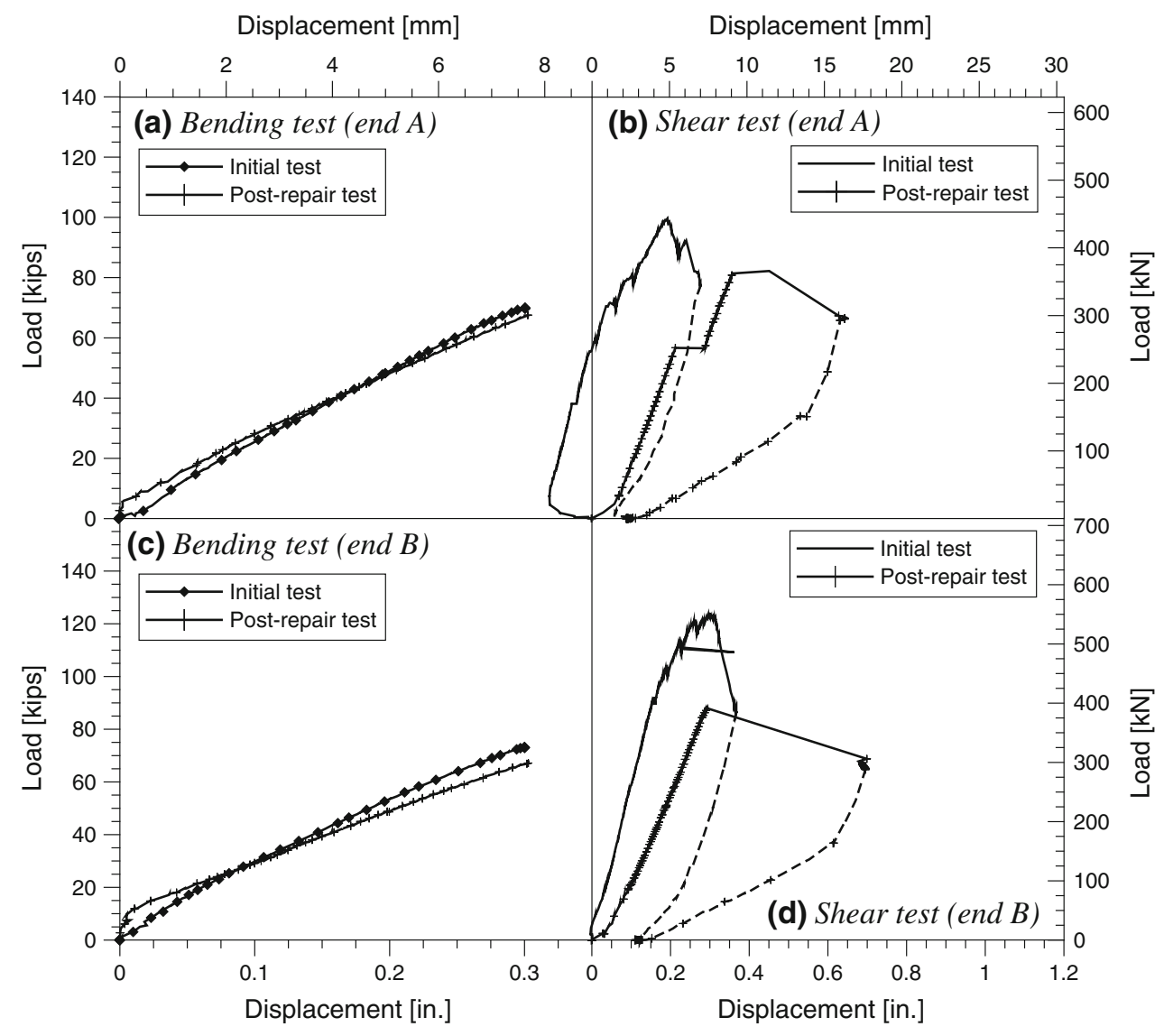

Fig. 9 Data from bending and shear tests of beam 1.

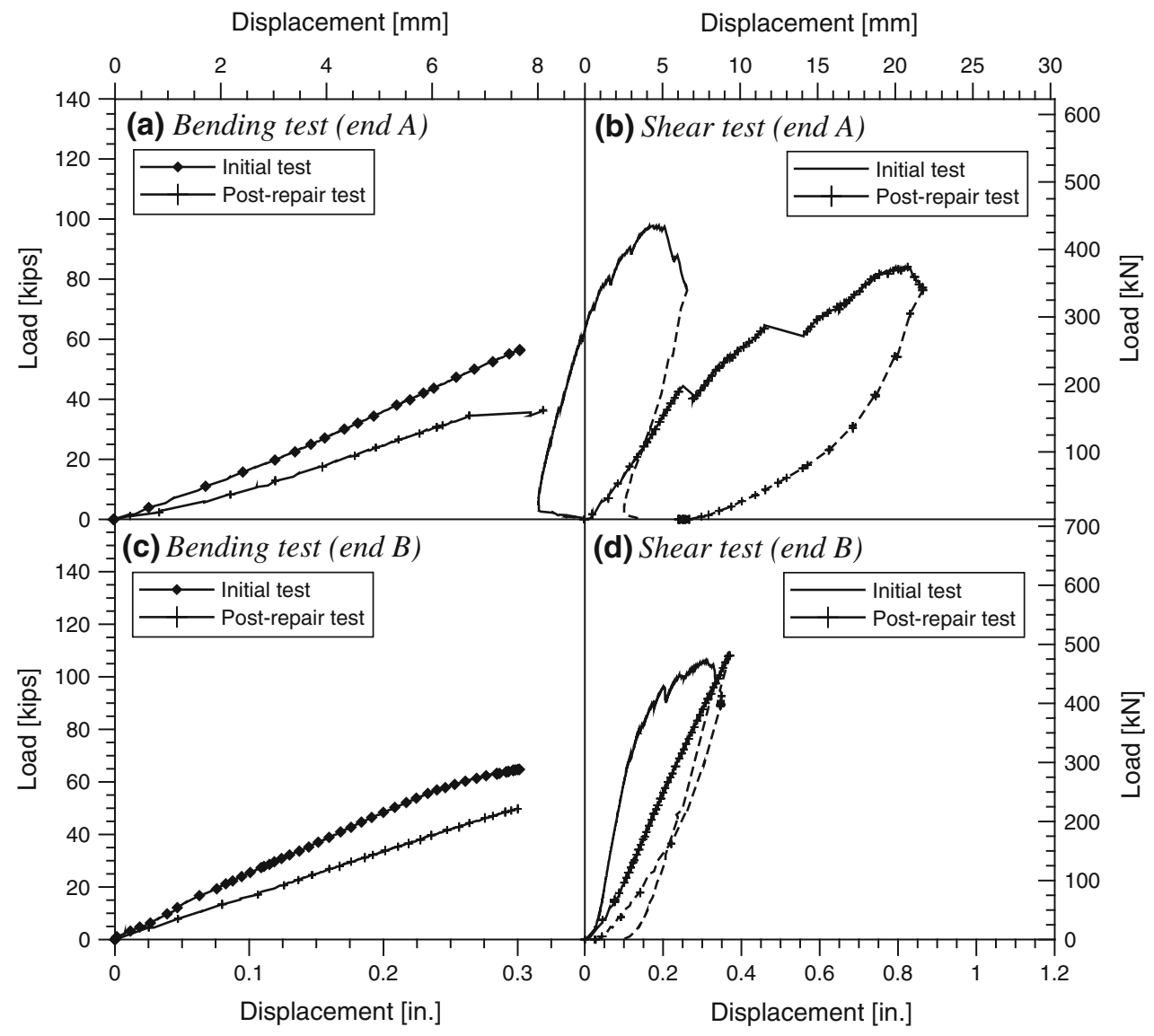

Fig. 10 Data from bending and shear tests of beam 2. 


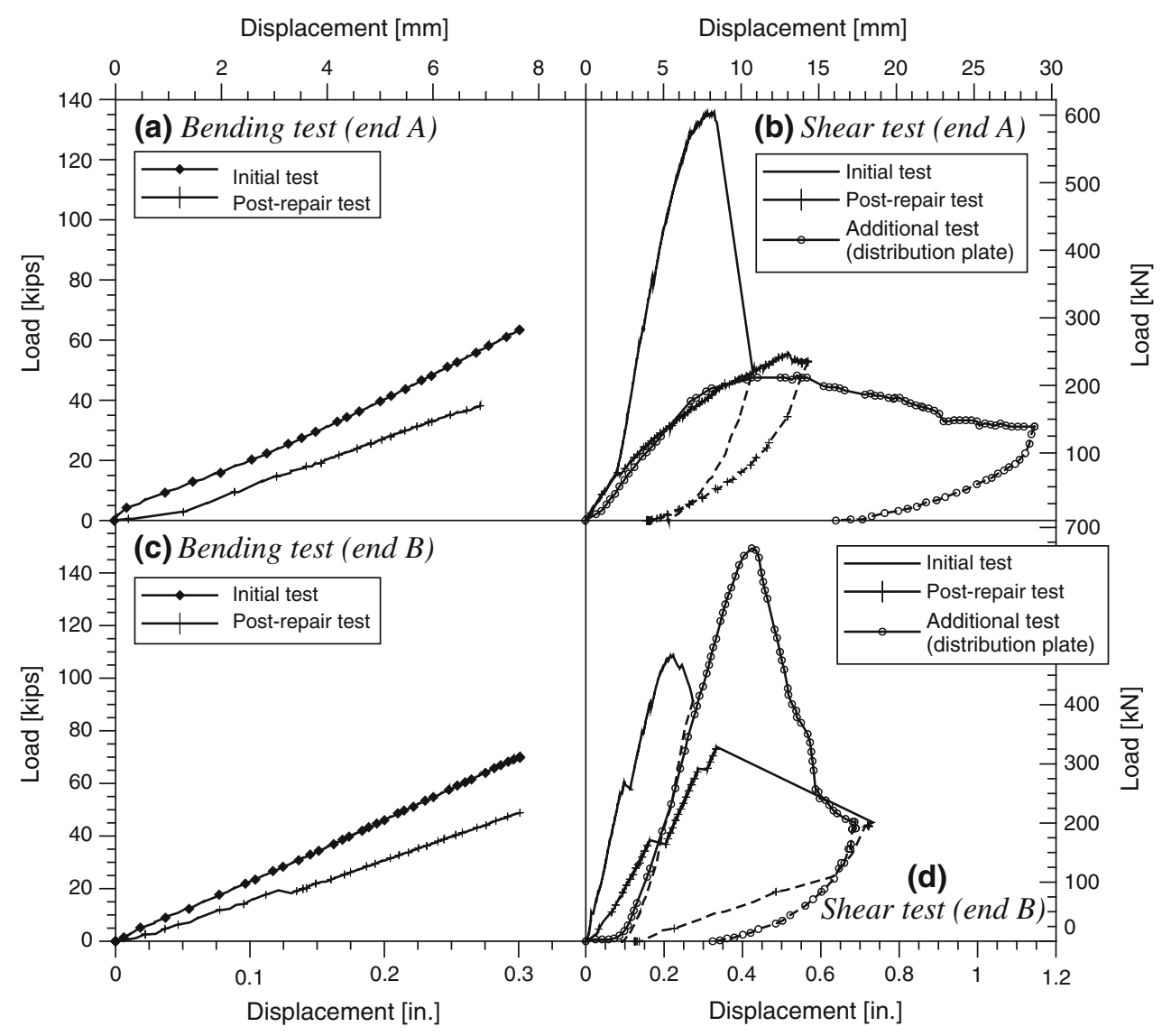

Fig. 11 Data from bending and shear tests of beam 3.

remaining case there was equality in the bending load achieved while the injected end provided a higher overall shear strength, supporting the conclusion that epoxy injections as an aid to repair methods provide a degree of help over beam ends not injected with epoxy.

Reviewing the different repairs, it was concluded that the carbon FRP has the greatest amount of stiffness recovery and the glass FRP has the highest percentage of overall strength recovery. Finally it was found that the use of a distribution plate along with the surface mounted rods provides the greatest potential for strength recovery, or in the best case scenario, strength gain. To validate the concept, however, numerical analyses should be carried out as a future study.

\section{Acknowledgments}

The research presented in this paper was supported by the Oklahoma Turnpike Authority and by the National Research Foundation of Korea (NRF) Grant funded by the Korea government (MEST) (No. 2012005905). The opinions, findings and conclusions in this paper are those of the authors and do not necessarily represent those of the sponsors.

\section{Open Access}

This article is distributed under the terms of the Creative Commons Attribution License which permits any use, distribution, and reproduction in any medium, provided the original author(s) and the source are credited.

\section{References}

ACI Committee 201. (1992). Guide to durable concrete (ACI 201.2R-92) (pp. 4). Farmington Hills: American Concrete Institute.

Emmons, P. H. (1994). Concrete repair and maintenance illustrated. Kingston: R. S. Means Company Inc.

Freeman, J. C., Haller, S. A., Hansen, D. M., Weitze, J. A., \& Martini, K. J. (1999). Seacoast fortifications preservation manual. San Francisco: GGNARA.

Koch, G. H., Brongers, P. H., Thompson, N. G., Virmani, Y. P., \& Payer, J. H. (2002). Corrosion cost and prevention strategies in the United States, Report No. FHWA-RD-01156, Federal Highway Administration, Washington, DC, pp. 12.

Needham, D. E. (2000). Prestressed concrete beam end repair. Research Report R-1380, Michigan Department of Transportation, Lansing, pp. 17.

U.S. Department of Transportation. (2004). Federal highway administration: National Bridge Inventory, Washington DC.

Weyers, R. E., Prowell, B. D., Sprinkel, M. M., \& Vorster, M. (1993). Concrete bridge protection, repair, and 
rehabilitation relative to reinforcement corrosion: $A$ methods application manual, SHRP-S-360 (pp. 75). Washington, DC: National Research Council.

Yeager, C. (2007). Corrosion of pre-stressing strands used to construct bridge girders. MS Thesis, The University of Oklahoma, Norman, OK.
Yunovich, M., Thompson, N. G., \& Virmani, Y. P. (2003). Life cycle cost analysis for reinforced concrete bridge decks. Paper No. 03309 presented at CORROSION/03, San Diego, pp. 23. 